\title{
Modern approaches to estimation of feed value and to rationing in ruminant nutrition
}

\author{
B.D. Kalnitsky and E.L. Kharitonov \\ Russian Research Institute of Physiology, Biochemistry and Nutrition of Farm Animals, \\ Russian Academy of Agricultural Sciences \\ Borowsk 3, Kaluga Region 249010, Russian Federation
}

\begin{abstract}
In experiments on surgically modified ruminants were obtained data determining quantitatively conversion of feed components in the rumen and intestine and subsequently incorporation of conversion products into metabolic pool and utilization of substrates for biosynthesis of milk component and heat production. Parameters of transport, absorption and utilization of the substrates of carbohydrate, lipids and amino acids in the intestinal wall and mammary gland at different phases of lactation and feeding condition were defined. Factors influencing the ratio of substrate of energy metabolism to: feeding level, proportion of substrate absorption, lactation stadium. Conducted experiments indicate a necessity of future studies on protein and lipid metabolism for improvement of feeding standards for dairy cows.
\end{abstract}

KEY WORDS: milking cow, nutrition, metabolism, nutrient utilization

In intensive animal breeding, the load on evolutionarily ally developed physiological capacity of animals is rising and the possibility of different physiological and biochemical disturbances is increasing. Thus the great number of problems associated with the necessity of taking into account the nature and the mechanisms of high production, including biological relations and bounds that appear at the level of feed intake, digestion, metabolism and efficiency of substrate utilization for animal production. These problems must be solved to optimize animal management and nutrition.

The main problem in nutritional systems is the determination of animal requirements for energy and nutrients. This can be done by either empirical determination of total requirements for nutritional factors, as a rule, whole body requirements for crude nutrients and energy, or by factorial estimation of expenditures for complex physiological functions (maintenance, milk secretion, growth, pregnancy, etc.). 
The term ,intake/output", which is commonly used in empirical systems for productivity prediction, is not based on physiological knowledge of the nature of internal mechanisms. Therefore, the present system may be convenient only for experimental feeds, specific animals and for the conditions in which these experimental data were obtained. Otherwise, this system can not be used for any conjunctures. For example, at determination of feed value for maintenance carbohydrates and protein have a similar value as energy resource. Other results can be obtained in high-growing and lactating animals. Protein is utilized by them completely or primarily for their body weight gain or synthesis of milk protein. This means that it is not lost through metabolism or the synthesis and excretion of urca. Depending on the use of feed protein (as an energy source or for direct productive functions) errors in determination of protein energy value may reach $25 \%$. The correlations between variability and growth rate, age, composition of body weight gain, etc. are well-known.

The second (factorial) approach has some advantages because it includes the efficacy of more factors. However, the factorial system is based on numerous assumptions that are not always correct.

Figure 1 is a diagram of rumen and intestinal metabolism of feed organic components (non-protein nitrogen substances, soluble protein, insoluble protein, cellulose, hemicellulose, organic acids, soluble carbohydrates, starch, fat, lignin), formation of substrates-metabolites from them and their entry into the blood. As Figure 1 shows, meeting animal requirements for energy and nutrients finally will be possible by means of a set of nutrients derived not only from feed, but

\begin{tabular}{|c|c|c|c|}
\hline Ration & Absorbed & Blood & Milk \\
\hline $\begin{array}{l}\text { NPN } \\
\text { RDP } \\
\text { RUP } \\
\text { SP } \\
\text { Cellulose } \\
\text { Hemicellulose } \\
\text { Lipids } \\
\text { Sugar } \\
\text { Starch }\end{array}$ & \begin{tabular}{|l} 
Acetate \\
Propionate \\
Butyrate \\
Glucose \\
Amino acids \\
Fatty acids
\end{tabular} & $\begin{array}{l}\text { Acetate } \\
\text { Propionate } \\
\text { Ketone } \\
\text { Glucose } \\
\text { Amino acids } \\
\text { Fatty acids } \\
\text { Lactate } \\
\text { Heat }\end{array}$ & $\begin{array}{l}\text { Lactose } \\
\text { Protein } \\
\text { Fat }\end{array}$ \\
\hline
\end{tabular}

NPN - non-protein nitrogen, RDP - rumen degradable protein, RUP - rumen undegradable protein, $\mathrm{SP}$ - soluble protein, Heat - the rumen fermentation

Figure 1. Metabolism nutrients in cows 
from formation during digestion and secondary metabolism in tissues, which allows optimizing nutrition not only on the digestion level, but on the metabolic level too.

Energy is utilized with varied efficiency, depending on the direction of its use (maintenance, lactation, reproduction, growth or fattening of animals). Different degrees of utilization for different functions will depend on the substrate (nutrient) set represented in a diet. For example, the lowest heat increment $(15.4 \%)$ appears in case of using volatile fatty acids for maintenance, amino acids for protein synthesis, and lipids for fat deposition. Heat gain increases twofold (27.6\%) when using preformed (prepared) fatty acids in fat synthesis. As another example, the biochemical efficiency of feed carbohydrate conversion into milk fat through acetate is 65 to $70 \%$, and efficiency of feed fat conversion into milk fat is 94 to $97 \%$ (Baldwin et al., 1980). Considerable benefit can be obtained if every organ would be provided with an optimal set and quantity of essential, specified nutrients. To our regret, our knowledge about adequate requirements for substrates in some organs and tissues is limited. Nutritional science can be considered to be at a turning-point because the problem of supplying gross value (energy and protein) necessarily slips into determination of animal requirements for metabolites-substrates, into development of methods for optimizing their formation and use for the purpose of more economic feed expenditure and further growth of animal production efficiency.

Our results and those of other studies show that new systems of animal nutrition must predict not only the quantity of metabolizable energy that enters into the animal's metabolic pool, but also quantity of some essential substrates-nutrients. Therefore, new nutritional systemis must also account for animal requirements for some metabolites or substrates.

For development and elaboration of ruminant nutritional systems and physiologically founded estimation of feed and diet values, more knowledge about quantitative conversion of the main components of some feeds in different parts of the digestive tract and subsequent conversion of adsorbed products into substratesnutrients of final metabolic reactions into production, heat production and byproducts of metabolism is needed.

\section{METHODS}

Against this background, at our Institute we use animals that have undergone complex operative preparation (rumen and duodenum cannulas, external anastomosis, vessel cannulas, blood flow sensor installation) to study the quantitative parameters of rumen formation of substrates, their transport, metabolism and utilization for milk synthesis. 


\section{RESULTS}

It is necessary to know the true nutrient digestibility of some feeds to determine the quantitative formation parameters of digestion end-products. Lack of information about reutilization of many elements and metabolites remains the limiting factor for determination of true digestibility and adsorption from the digestive tract. There is insufficient data about the influence of lactation stage, dry-milking, nutritional level and diet composition on digestion. Endogenous nitrogen reaching the forestomachs of ruminants consists of saliva protein, protein of epithelium scaled from rumen walls, blood protein diffused through rumen walls, and abomasum juice protein. Thus, in cows with a liveweight of $450-500 \mathrm{~kg}$ (fourth month of lactation) fed $2000 \mathrm{~g}$ crude protein with feed about $200 \mathrm{~g}$ of endogenous protein, or $0.32 \mathrm{~g}$ protein nitrogen per $\mathrm{kg}$ metabolic weight, are supplied. This is equal to $10 \%$ nitrogen as fed with feed, or about $12 \%$ total digesta nitrogen supplied in the small intestine. We must not omit this figure when determining the true parameters of nitrogen digestibility and definition of nutritional standards because deposition of endogenous nitrogen into animal protein (nitrogen) compounds is fairly significant.

Quantitative parameters of substrates supplied from the digestive tract of dairy cows were obtained based on established fundamental patterns of feed nutrient conversion in the rumen and intestine into digestion end-products. The contents and fermentation rates of starch, cellulose, hemicellulose, protein fractions and amino acid metabolism rates of specific feeds were determined. Correlations of intestinal digestion of feed protein (Figures 2 and 3), starch, lipids and some amino acids and degree of their conversion in the rumen were obtained. To calculate evacuation rates, complicated regression equations in which the dependence of intensity of feed particles supplied from the rumen on nutrition parameters were included, were formulated.

For sheep

$\mathrm{RK}=0.05 \mathrm{DMI} / \mathrm{MBW}+0.04(\% \mathrm{NDF})-0.88$ at $\mathrm{r}=0.79, \mathrm{n}=18$

for cows

$\mathrm{RK}=0.048 \mathrm{DMI} / \mathrm{MBW}+0.0055(\% \mathrm{NDF})-1.87$ at $\mathrm{r}=0.96, \mathrm{n}=37$

where

DIM - DM intake, $g$

MBW - metabolizable body weight (liveweight raised to 0.75 power), $\mathrm{kg}$ $\%$ NDF - percentage contents of rough feed NDF in a diet $\mathrm{R} \kappa$ - outflow rate of rumen content solid fraction from rumen, $\% / \mathrm{h}$

Based on fractional digestibility of structural and non-structural carbohydrates and fermentation status, quantitative parameters of VFA secretion were calculated. 
KALNITSKY B.D., KHARITONOV E.L.

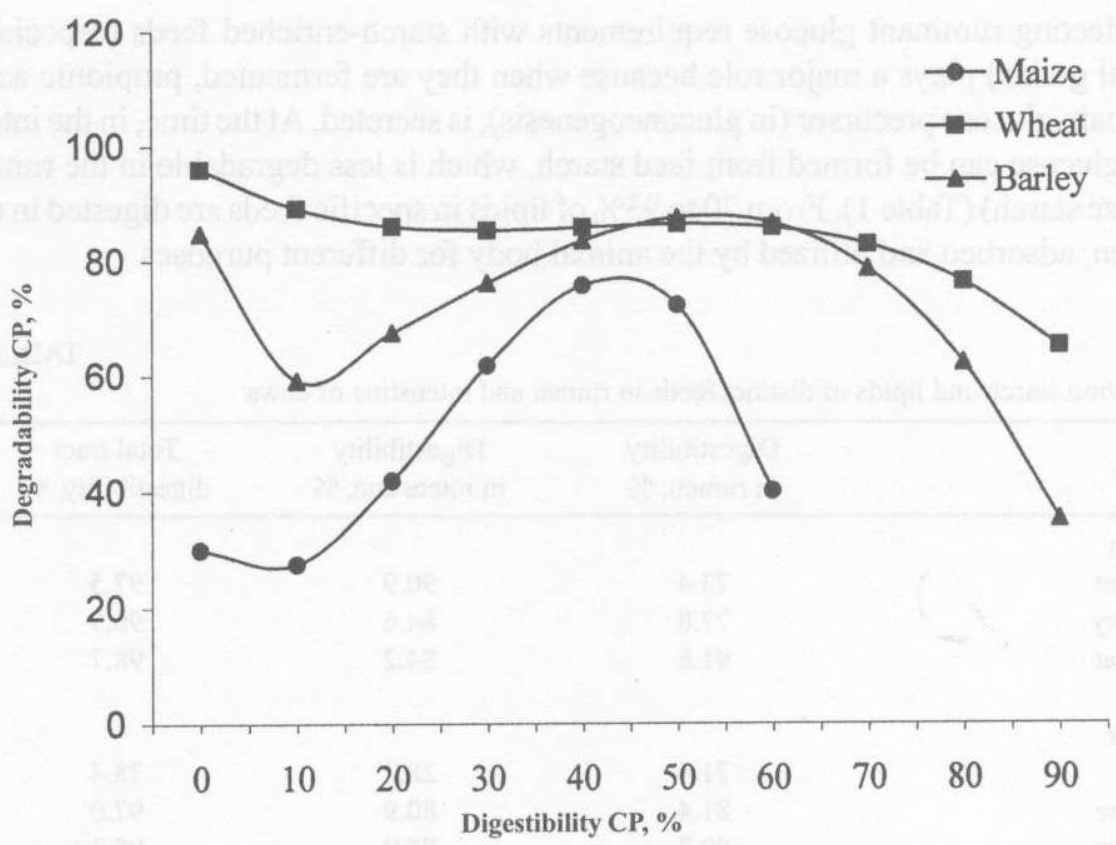

Figure 2. Dependence of digestion $\mathrm{CP}$ in intestinal from $\mathrm{CP}$ degradability in rumen

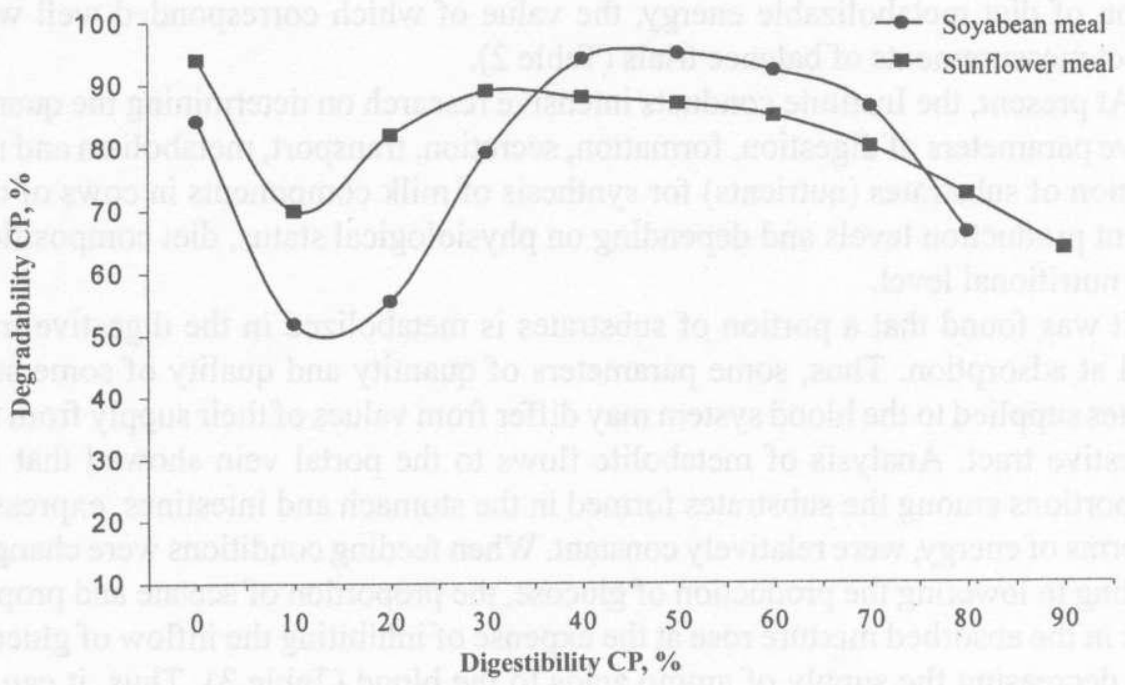

Figure 3. Dependence of digestion $\mathrm{CP}$ in intestinal from $\mathrm{CP}$ degradability in rumen 
Meeting ruminant glucose requirements with starch-enriched feeds (especially cereal grains) plays a major role because when they are fermented, propionic acid, the main glucose precursor (in gluconeogenesis), is secreted. At the time, in the intestine glucose can be formed from feed starch, which is less degradable in the rumen (maize starch) (Table 1). From 70 to $93 \%$ of lipids in specific feeds are digested in the rumen, adsorbed and utilized by the animal body for different purposes.

TABLE I

Digestion starch and lipids of distinct feeds in rumen and intenstine of cows

\begin{tabular}{lccc}
\hline Feeds & $\begin{array}{c}\text { Digestibility } \\
\text { in rumen, \% }\end{array}$ & $\begin{array}{c}\text { Digestibility } \\
\text { in intenstine, \% }\end{array}$ & $\begin{array}{c}\text { Total tract } \\
\text { digestibility, \% }\end{array}$ \\
\hline Starch & & & \\
maize & 73.4 & 90.9 & 97.5 \\
barlcy & 77.8 & 84.6 & 96.5 \\
wheat & 91.8 & 84.2 & 98.7 \\
Lipids & & & \\
hay & 71.4 & & 78.4 \\
maize & 81.4 & 28.2 & 97.0 \\
barley & 80.7 & 80.9 & 95.3 \\
wheat & 93.1 & 75.9 & 97.4 \\
soyabean meal & 80.5 & 62.4 & 93.7 \\
\hline
\end{tabular}

Determination of the whole set of formeded substrates made possible the calculation of diet metabolizable energy, the value of which corresponded well with direct measurements of balance trials (Table 2).

At present, the Institute conducts intensive research on determining the quantitative parameters of digestion, formation, secretion, transport, metabolism and utilization of substrates (nutrients) for synthesis of milk components in cows of different production levels and depending on physiological status, diet composition, and nutritional level.

It was found that a portion of substrates is metabolized in the digestive tract wall at adsorption. Thus, some parameters of quantity and quality of some substrates supplied to the blood system may differ from values of their supply from the digestive tract. Analysis of metabolite flows to the portal vein showed that the proportions among the substrates formed in the stomach and intestines, expressed in terms of encrgy, were relatively constant. When feeding conditions were changed leading to lowering the production of glucose, the proportion of acetate and propionate in the absorbed mixture rose at the expense of inhibiting the inflow of glucose and decreasing the supply of amino acids to the blood (Table 3). Thus, it can be concluded that redistribution of substrates in energy metabolism appears to occur 
TABLE 2

Production of substrates and metabolites in a digestive tract of the cows at the standard feeding depending on ration structure, g/day

\begin{tabular}{|c|c|c|c|c|c|c|}
\hline \multirow{4}{*}{ Indices } & \multirow{4}{*}{$\begin{array}{c}\text { Hay- } \\
\text { concentrate } \\
50: 50 \\
\text { beginning } \\
\text { of lactation }\end{array}$} & \multirow{4}{*}{$\begin{array}{l}\text { Silage-hay- } \\
\text { concentrate } \\
65 \text { (conc.): } \\
20 \text { (beets.): } \\
15 \text { (forage) }\end{array}$} & \multirow{4}{*}{$\begin{array}{c}\text { Silage-hay- } \\
\text { concentrate } \\
30 \text { (conc.): } \\
5 \text { (beet): } \\
65 \text { (forage) }\end{array}$} & \multicolumn{2}{|c|}{$\begin{array}{l}\text { Green forage with } \\
\text { concentrates }\end{array}$} & \multirow{4}{*}{$\begin{array}{c}\text { Hay- } \\
\text { concentrate } \\
35 \text { (conc): } \\
65 \text { (hay) } \\
\text { dry period }\end{array}$} \\
\hline & & & & \multirow{3}{*}{$50: 50$} & 30 (conc): & \\
\hline & & & & & & \\
\hline & & & & & 70 (green) & \\
\hline Amino acids & 1486 & 1135 & 1142 & 1243 & 1182 & 965 \\
\hline Glucose & 800 & 771 & 687 & 761 & 658 & 518 \\
\hline Acetate & 3520 & 2820 & 2840 & 2760 & 2800 & 2076 \\
\hline Propionate & 1710 & 1440 & 1280 & 1320 & 1280 & 960 \\
\hline Butyrate & 811 & 666 & 619 & 624 & 613 & 462 \\
\hline Fatty acids & 153 & 193 & 208 & 251 & 253 & 104 \\
\hline Metabolizable & & & & & & \\
\hline energy, $\mathrm{MJ}^{*}$ & 165 & 127.8 & 125 & 132 & 130 & 97 \\
\hline Energy of absorbed & & & & & & \\
\hline substrates, MJ & 160 & 133 & 128 & 133 & 130 & 96.5 \\
\hline
\end{tabular}

* data obtained in balance trials

TABLE 3

Formation and uptake of nutrients from gastrointestinal tract in blood

\begin{tabular}{|c|c|c|c|c|c|c|c|c|c|}
\hline \multirow{3}{*}{ Nutrients } & \multicolumn{9}{|c|}{ Produced in digestive tract for absorption } \\
\hline & \multicolumn{3}{|c|}{1 trial } & \multicolumn{3}{|c|}{2 trial } & \multicolumn{3}{|c|}{3 trial } \\
\hline & G & MJ & $\%$ & $\mathrm{~g}$ & MJ & $\%$ & $\mathrm{~g}$ & $\mathrm{MJ}$ & $\%$ \\
\hline Acetate & 2016 & 28.6 & 19.7 & 1950 & 27.7 & 22.7 & 2338 & 33.3 & 25.5 \\
\hline Propionate & 721 & 14.5 & 10.0 & 706 & 14.2 & 11.6 & 754 & 15.2 & 11.7 \\
\hline Butyrate & 623 & 15.0 & 10.3 & 549 & 13.3 & 10.8 & 611 & 14.8 & 11.3 \\
\hline Glucose & 1466 & 23.4 & 16.1 & 200 & 3.2 & 2.6 & 200 & 3.2 & 2.4 \\
\hline Amino acids & 1400 & 33.6 & 23.1 & 1400 & 33.6 & 27.5 & 1400 & 33.6 & 25.8 \\
\hline Fatty acids & 750 & 30.0 & 20.6 & 750 & 30.0 & 24.5 & 750 & 30.0 & 23.0 \\
\hline \multicolumn{10}{|c|}{ Transported into the blood } \\
\hline Acetate & 1848 & 26.3 & $24.3^{*}$ & 1305 & 18.5 & 30.4 & 1853 & 26.3 & 28.1 \\
\hline Propionate & 277 & 5.6 & 5.1 & 416 & 8.4 & 15.5 & 739 & 14.9 & 16.0 \\
\hline Butyrate & 239 & 5.7 & 5.3 & 204 & 4.9 & 6.5 & 244 & 5.9 & 6.3 \\
\hline Ketone bodies & 160 & 3.1 & 2.8 & 0 & 0 & 0 & 214 & 4.1 & 4.4 \\
\hline Glucose & 766 & 12.2 & 11.2 & -481 & -7.6 & - & -306 & -4.8 & - \\
\hline Aminoacids & 946 & 22.7 & 20.9 & 743 & 17.8 & 24.0 & 602 & 14.4 & 25.4 \\
\hline Fatty acids & 750 & 30.0 & 27.7 & 750 & 30 & 40.2 & 750 & 30.0 & 32.0 \\
\hline
\end{tabular}


upon their adsorption in the digestive tract wall. It was noted that delivering some substrates to the blood depended on their concentration in the blood flow, which is characteristic of other organs (mammary gland), and even more on the production and absorption of other metabolites, e.g., propionate and acetate absorption depended on the level of glucose and amino acid production.

We studied parameters that can influence energy metabolism substrate ratios, e.g., nutritional level, adsorbed substrates ratio, lactation stage. In heat production analysis we determined the preferential use of fatty acids in energy metabolism in cows at the beginning of lactation when acetate oxidation decreased significantly (2-2.5 fold), this was associated with reserve energy resource mobilization and low feed intake (Figure 4).

We studied basal stages of amino acid conversion in dairy cows, e.g., adsorption, metabolism and utilization for milk protein synthesis, to estimate meeting animal limiting amino acid requirements.

When acetate was infused into venous blood, we observed a difference in the ratio of substrates absorbed in the mammary gland. When different nutrients were infused into the digestive tract, similar results on mammary-adsorbed metabolites with daily registration of blood flow volume rate were obtained.

To study redistribution of mammary-adsorbed metabolites at different levels in the blood flow, a trial using lactating cows was conducted. Beside the basal diet, some nutrients (acetate, fatty acids, glucose, amino acids and their combinations) were infused into the rumen and intestine to alter the ratio of metabolizable energy substrates (Figure 5). Our findings point to a correlation between metabolite ad-

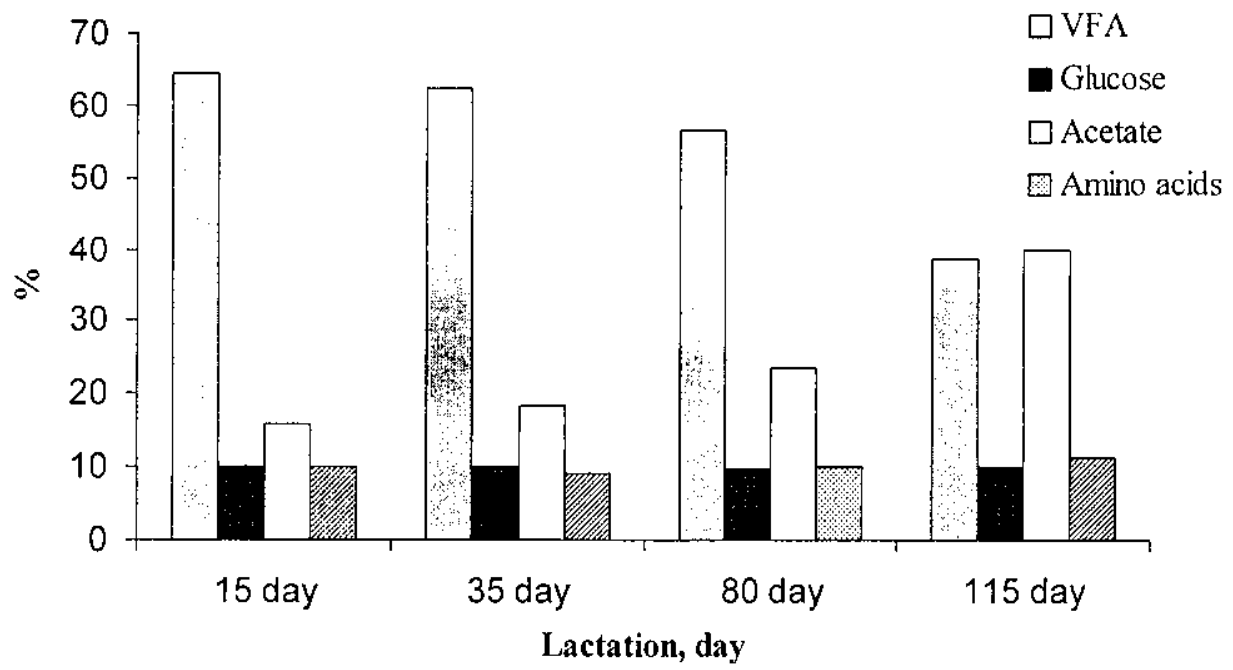

Figure 4. Use of substrates at formation of heat 

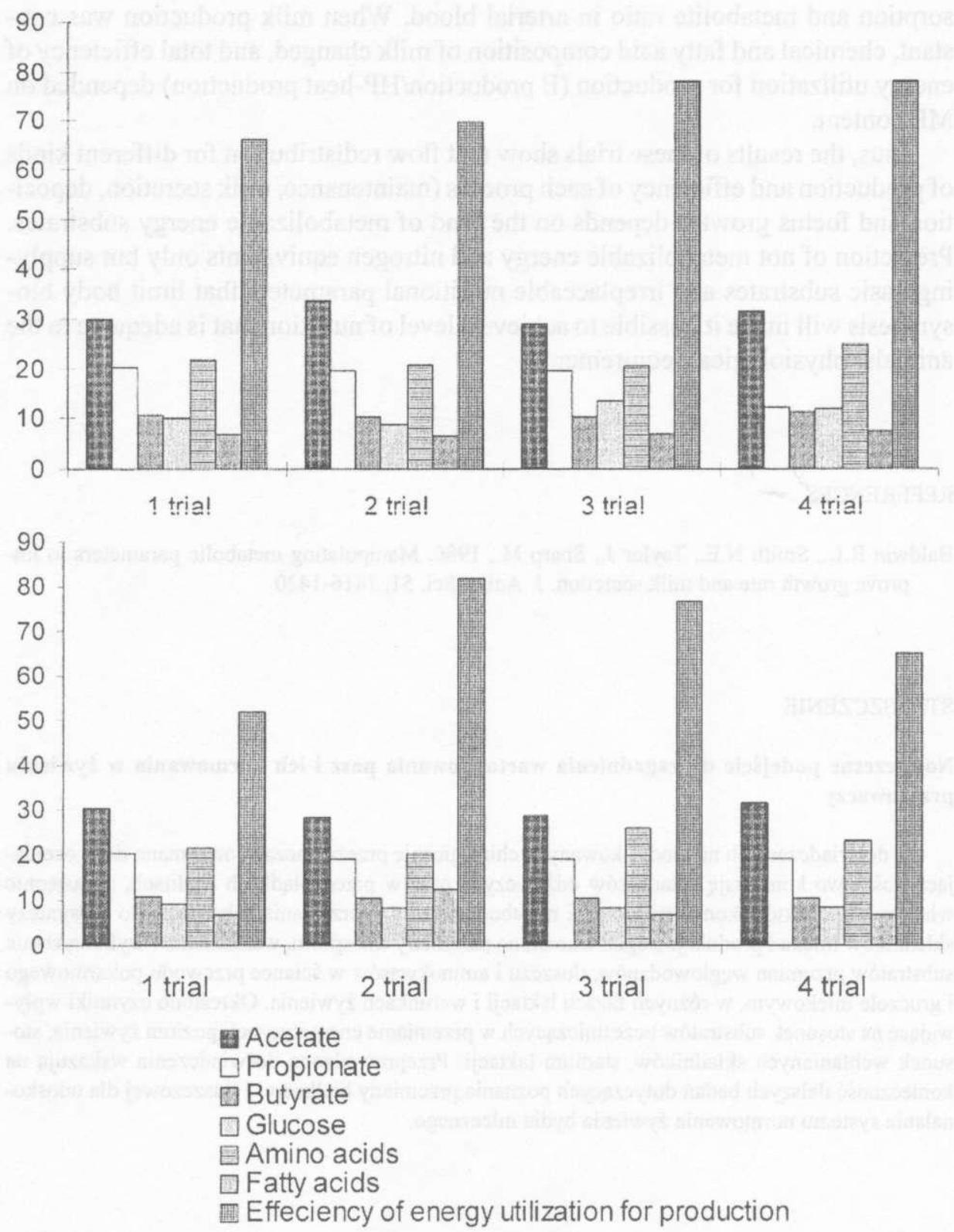

Figure 5. Absorption of nutrients from the gastro intestinal tract ( $\%$ by energy) and efficiency of metabolisable energy utilization for production in cow

a. Trial 1 - control, Trial 2 - increase of acetate, 3 - glucose, 4 - amino acids and glucose;

b. Trial 1 - control, Trial 2 - increase of FA ratio, 3 - increase of amino acids, 4 - increase of acetate and amino acids 
sorption and metabolite ratio in arterial blood. When milk production was constant, chemical and fatty acid composition of milk changed, and total efficiency of energy utilization for production (E production/HP-heat production) depended on ME content.

Thus, the results of these trials show that flow redistribution for different kinds of production and efficiency of each process (maintenance, milk secretion, deposition and foetus growth) depends on the kind of metabolizable energy substrates. Prediction of not metabolizable energy and nitrogen equivalents only but supplying basic substrates and irreplaceable nutritional parameters that limit body biosynthesis will make it possible to achieve a level of nutrition that is adequate to the animals' physiological requirements.

\section{REFERENCES}

Baldwin R.L., Smith N.E., Taylor J., Sharp M., 1980. Manipulating metabolic parameters to improve growth rate and milk secretion. J. Anim. Sci. 51, 1416-1420

\section{STRESZCZENIE}

Nowoczesne podejście do zagadnienia wartościowania pasz $i$ ich normowania $w$ żywieniu przeżuwaczy

W doświadczeniach na modyfikowanych chirurgicznie przeżuwaczach otrzymano dane oceniające ilościowo konwersję składników odżywczych pasz w przedżołądkach i jelitach, a następnie włączania produktów konwersji do puli metabolicznej i wykorzystania substratów do biosyntezy składników mleka i produkcji ciepła. Określono parametry transportu, wchłaniania i wykorzystania substratów przemian węglowodanów, tłuszczu i aminokwasów w ściance przewodu pokarmowego i gruczole mlekowym, w różnych fazach laktacji i warunkach żywienia. Określono czynniki wpływające na stosunek substratów uczestniczących w przemianie energetycznej: poziom żywienia, stosunek wchłanianych składników, stadium laktacji. Przeprowadzone doświadczenia wskazują na konieczność dalszych badań dotyczących poznania przemiany białkowej i thuszczowej dla udoskonalania systemu normowania żywienia bydła mlecznego. 